\title{
The Effects of the COVID-19 Pandemic on University Student Enrollment Decisions and Higher Education Resource Allocation
}

\author{
Aurore J. Kamssu \\ Tennessee State University \\ R. Barbara Kouam \\ Eni Trading and Shipping
}

The uncertainty created by the COVID-19 pandemic has anguished both college students and university administrators around the world. Leading up to the 2020-2021 academic year, college students were not certain of when their universities would reopen or of how they would pay for school, given the financial unpredictability. Many students opted to defer their enrollment or re-evaluate their first-choice institution. Universities also faced financial pressure as student enrollment dropped while institutions incurred new costs, investing in student and employee safety measures as well as in IT solutions for distance education: online program management platforms and other tools related to students' online learning experience and data collection.

Keywords: COVID-19, pandemic, higher education, information technology, distance learning, remote learning, university digitalization

\section{INTRODUCTION}

The digitalization of universities evolved over the years, as digital technology has become an integral part of higher education. To be competitive, universities must establish and maintain an online presence by either offering hybrid courses, launching entire online programs, or establishing themselves as complete online universities. Before the pandemic, traditional higher education institutions developed online programs to attract students from a wider range of locations. Since 2020, online learning has become the norm at higher education institutions (DeVaney, et al., 2020). However, the massive transition to online learning due to COVID-19, had a more significant impact on students and other universities stakeholders than previous incidents had with online learning. In fact, students and university administrators are now reassessing the need for the traditional immersive college experience, evaluating the impact of the traditional experience on students' finances, on student selection of universities, and on university budgets.

This study examines the many ways students' college decisions are affected by the COVID-19 pandemic and evaluates whether this effect varies depending on the ranking of the school, the type of school (public or private), and the distance between the institution and the student's hometown. The study also analyzes the effects of the pandemic on higher education institutions, particularly with regards to their allocation of resources and the students' reaction to those reallocations. 


\section{IMPACTS OF THE PANDEMIC ON STUDENT ENROLLMENT DECISIONS}

Students' choice of college is a significant predictor of future income and therefore a major decision that can affect the rest of their lives. On average, over their lifetime, college graduates earn more than twice as much as typical high school graduates (Hershbein \& Kearney, 2014). In addition, education leads to life choices that promote better health, less reliance on social safety net programs, and fewer encounters with the criminal justice system (Oreopoulos \& Salvanes, 2011; Acton, 2020). However, lockdowns and safety restrictions caused by the pandemic have affected student decisions about attending college. Cost and location are the primary factors that guide students' choice of college, and remote learning has minimized the factor of location, while amplifying the tradeoff between value for cost. Digitalization has contributed to the decision-making process, as students are able to experience campus previews using digital technology. Prospective students can now take virtual campus tours, connect to current students through social media sites, and schedule video calls with alumni to gain more information about their prospective universities (Shulman, 2020). However, digitalization has its drawbacks. Online courses can pose a dilemma for international students as they must decide whether to pay for expensive accommodations in the US or stay in their country of origin since classes are online (Beckstein, 2020).

\section{American Students}

Due to the COVID-19 pandemic, students graduating in 2020 ended their high school years in a vastly different environment than the previous graduating class. The COVID-19 pandemic directly affected both college campuses and students' family situations which in turn impacted the class of 2020's college selection decisions. High school seniors were questioned by Art \& Science Group LLC. (2020) in March and April 2020 about how their college decisions were impacted by the pandemic. The survey showed that $65 \%$ of students expressed concerns about the ability to attend their first-choice school due to affordability though they still planned to enroll in a 4-year program; $17 \%$ of students changed their plans, choosing to take a gap year, enroll part time for a semester or two, or attend community college and transfer to the college of their choice later. Korn (2020) also stated that many students who altered their plan because of the pandemic have in mind to transfer back to their dream schools or to other schools. However, research shows that many high school graduates who put off college never go back and only $13 \%$ of community college students end-up in a 4-year university (Marcus, 2020).

\section{Deferment}

A major cause of enrollment decline is deferment. The decrease in enrollment at top-tier private schools in 2020 has mainly been due to the increase in enrollment deferment. In August 2020, the Boston Globe reported that $20 \%$ of first-year students at Harvard University opted to defer their admission and take a gap year rather than start their elite education online amid the COVID-19 pandemic; by the same token, the deferment rate for first year students at The Massachusetts Institute of Technology (MIT) rose from 1\% pre-pandemic to 8\% in 2020 (Krantz \& Fernandes, 2020). By contrast, public schools experienced only a smaller percentage of deferments; for instance, the University of Massachusetts' deferment rate was only $1.2 \%$ in 2020 .

\section{Uncertainty}

Students are expressing uncertainty about their college plans. A study of 273 incoming freshmen from 2020 reports that $40 \%$ of incoming freshmen said they were likely or highly likely to change their choice of schools due to the pandemic (Simpson Scarborough, 2020). Korn (2020) reported that some students decided to cut down on expenses by remaining home as long as classes were offered online and would move on campus if needed the following year. There is also an increasing trend of students opting for instate public schools closer to home rather than for out-of-state institutions. FIGURE 1 presents the change in students' first choice of institutions before and after the pandemic. Cost and location are clearly strong driving forces in these preference changes. 


\section{FIGURE 1 \\ STUDENTS ARE CHANGING THEIR FIRST-CHOICE INSTITUTION DUE TO COST AND LOCATION}

\begin{tabular}{|c|c|c|c|c|c|c|c|}
\hline \multicolumn{4}{|c|}{$\begin{array}{l}\text { Institution sector of first-choice colleges before } \\
\text { and after COVID-19, } \% \text { of respondents }(n=273)^{2}\end{array}$} & \multicolumn{4}{|c|}{$\begin{array}{l}\text { Distance from respondents to their first-choice } \\
\text { colleges before and after COVID-19, } 1 \% \text { of } \\
\text { respondents }(n=267)^{3}\end{array}$} \\
\hline Different state, private & 33 & 28 & & Over 500 miles & 35 & 28 & \\
\hline Different state, public & 23 & 19 & & 200-500 miles & 16 & 15 & \\
\hline Same state, private & 14 & & $+10 p p^{4}$ & $100-200$ miles & 17 & 14 & \\
\hline \multirow[t]{2}{*}{ Same state, public } & 30 & 40 & & $\begin{array}{l}50-100 \text { miles } \\
\text { Under } 50 \text { miles }\end{array}$ & 11 & 32 & $+11 p p^{4}$ \\
\hline & $\begin{array}{l}\text { Previous } \\
\text { first choice }\end{array}$ & $\begin{array}{l}\text { New first } \\
\text { choice }\end{array}$ & & & $\begin{array}{l}\text { Previous } \\
\text { first choice }\end{array}$ & $\begin{array}{l}\text { New first } \\
\text { choice }\end{array}$ & \\
\hline \multicolumn{8}{|c|}{ 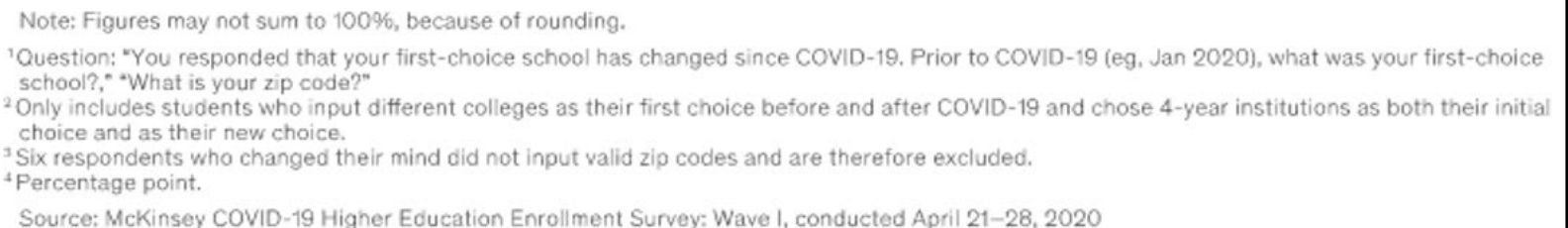 } \\
\hline
\end{tabular}

Kim, Krishnan, Law, \& Rounsville, 2020

\section{Enrollment}

In addition, the effect on students is unevenly distributed: 2020 enrollment data shows that the student groups that decreased enrollment in greatest proportions in 2020 were American Indian and Native Alaskan, at $-10.7 \%$ and Black students at $-7.9 \%$. This was followed by White, Hispanic, and then Asian students. Undergraduate international students experienced a double-digit drop at -13.7\% (Sedmak, 2020).

Another reason for enrollment decline is education costs. Economic considerations resulting from the pandemic prompted some students not to attend their first choice of college. For example, Korn (2020) reported that a senior from California, who originally wanted to attend a big, out-of-state university with a lot of school spirit, began to rethink her preference for the University of Oregon after considering that she would be paying $\$ 53,000$ for what would likely be online schooling. She thus changed her mind and decided to go to a community college near her hometown for a fraction of that price.

Private institutions were expected to experience fewer student enrollment as a result of the pandemic. During the 2020-2021 school year, Harvard administration expected enrollment to decrease by about 1470 students, which is $1 / 4$ of the usual undergraduate student body (Krantz \& Fernandes, 2020). Along the same line, Stanford reported admitting fewer students than targeted, even after accepting waitlisted students (Ehsan, 2020). Some public schools, on the other hand, are seeing the reverse trend as the University of Massachusetts saw a 10\% increase in first-year deposits. The University of Tennessee at Knoxville (UTK), a public largely in-state school, saw a $4.9 \%$ increase in the number of first-time freshmen enrolled in 2020 (OIR UTK, 2020). 
FIGURE 2

UNIVERSITY OF TENNESSEE, KNOXVILLE, A PUBLIC UNIVERSITY, SEES A LARGE RATE INCREASE OF APPLICATIONS IN 2020

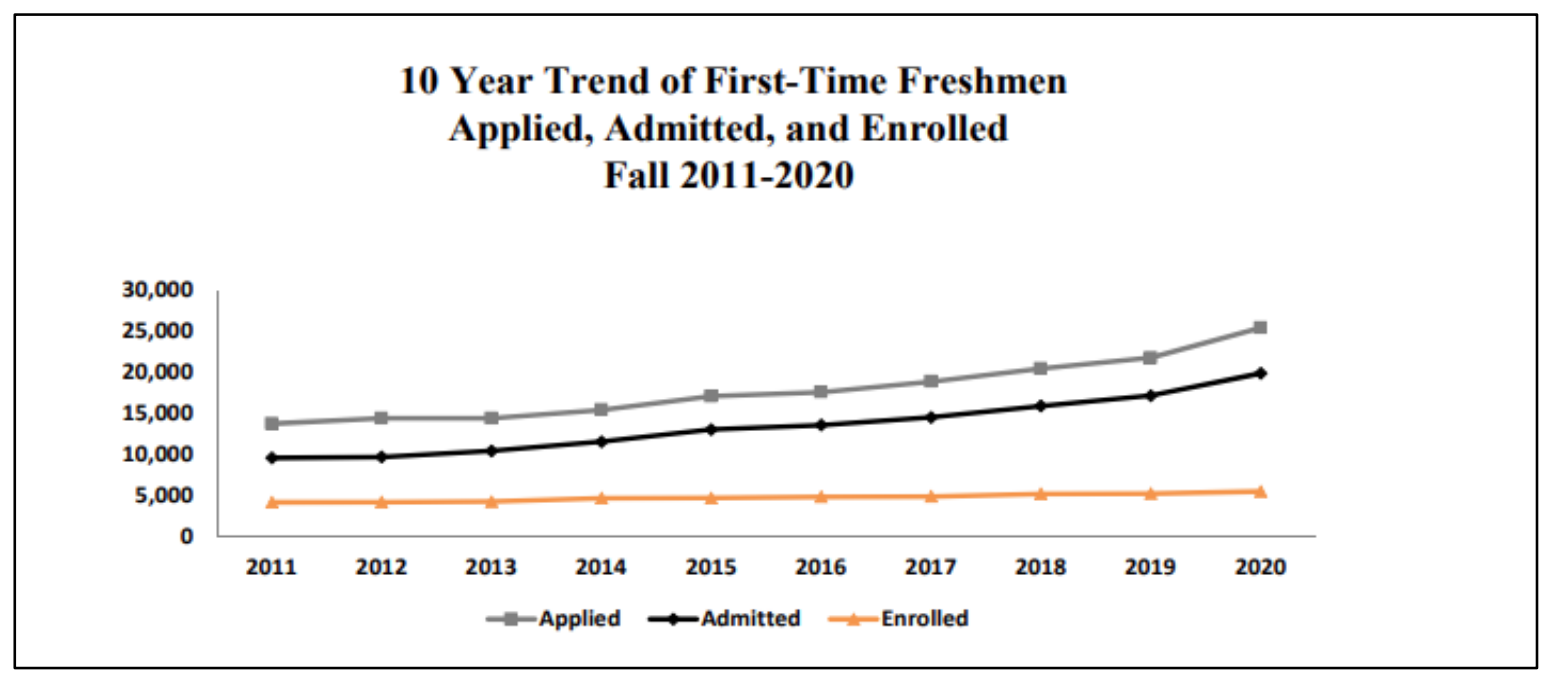

OIR UTK, 2020

Moreover, UTK's 10-year admissions data presented in FIGURE 2 shows that the application rate rose about $16.8 \%$ in 2020 , compared with $6.3 \%$ in 2019 . The 2020 application rate increase was the highest in 8 years, with average year-over-year admissions increasing at a rate of 5.94\%, excluding 2020 (OIR UTK, 2020). Smaller private schools are also seeing this trend. This increase in enrollment may be reserved to leading state institutions like UTK, as the pandemic caused a decrease in enrollment at many other state schools. The National Student Clearinghouse data suggests that enrollment at community colleges and public universities were down, although higher education enrollment numbers are up by about 3\% compared to 2019 for for-profit online four-year colleges (Sedmak, 2020). Students seem to behave differently toward admission to top-tier private, small private, in-state public and out-of-state public schools; as location seems to matter today more than ever before. McKinsey \& Company reports that, for the 2020-2021 academic year, more than 1/5 of students changed their first-choice school due to cost and location (Kim, et al., 2020). A Nashville local news reported that small private schools in Tennessee, including Lipscomb University, Fisk University and Cumberland University, had record enrollment growth in 2020 due to their strategic proximity to students' homes (Davis, 2020).

\section{International Students}

According to the Institute of International Education, the number of international students attending college in the United States grew by 3.5\% from the academic year 2010-11 to about 1.1 million international students in the academic year 2018-19 (Kelly \& Columbus, 2020). However, as higher education institutions restructure their daily operations to survive the COVID-19 pandemic, recruiting and handling international students has become increasingly challenging.

\section{Language and Cultural Challenges}

According to Dr. Stephine Chong, international students are dealing with additional stressors due to COVID-19, including uncertainty and increased levels of isolation. These factors are affecting the mental health of many international students, adding to the typical challenges of culture and language barriers. Many international students have found the shift to online learning more challenging than helpful. Dr. Chong explained that remote learning can add more stress for international students who already struggle with language and cultural differences as they are likely to miss important social cues that are difficult to view on screens (Beckstein, 2020). 


\section{Student Visa Requirements}

The Department of Homeland Security temporarily changed United States visa rules to accommodate international students during the pandemic. This gave those international students who were already attending university the option to travel back home to finish school virtually or to stay in the US while completing their classes online. However, international students living in dormitories who choose to stay in the US suddenly had to find alternate housing accommodations as campuses closed due to COVID-19. Emma Israel and Jeanne Batalova (2021) explain:

"Closures and limited access to U.S. embassies and consulates, travel restrictions, and personal safety considerations have complicated visa issuance and travel plans of international students. The Trump administration initially attempted to bar students from entering or remaining in the United States if their schools offered only online courses, although the order was quickly rescinded. Still, the move contributed to confusion and frustration for U.S. colleges and universities and their international students. At the start of the fall 2020 academic semester, the total number of international students enrolled in U.S. schools, including those physically present in the United States and studying online from abroad, decreased by 16 percent from the previous year. One in five of these students was studying online from another country. The number of new international students fell by 43 percent, in part because some chose to defer their studies." (para. 2)

Despite the initial confusion, the Department of Homeland Security adjusted their visa rules to allow foreign students who went back to their home countries the right to keep their student visas as long as they remained enrolled in online classes at a US university. International high school students must now factor the pandemic, travel restrictions, and immigration rules before considering whether to apply for universities in the US. These additional considerations will affect international students' enrollment in US colleges and universities for the coming years. In any case, whether international or domestic, high school seniors are now carefully considering their college decisions, evaluating financial, social, and legal changes due to the pandemic.

\section{IMPACTS OF THE PANDEMIC ON ACADEMIC DELIVERY}

The COVID-19 pandemic caused great concern not just to students, but also to institutions of higher education across the United States. Colleges and universities were forced to make rapid transitions to remote teaching and learning, yet remote learning requires adjustments in time and effort from professors and university administrations to effectively plan teaching in a fully online environment. As the pandemic triggered shifts to remote learning, colleges and universities were forced to change their strategy and adjust their day-to-day operations. Schools began trying to understand how online delivery methods of academic education affect the overall college experience, and some even questioned if students should benefit from price reductions for online instruction.

\section{Delivering Academic Education}

As colleges and universities continue to adjust to the pandemic, distance learning has intensified. Smart technology and digital information allow universities to automate some tasks as they mobilize instructional designers, trainers, and coaches to ensure student learning and course completion (Williamson, 2020). To this end, higher education institutions must secure strong IT infrastructure, IT support staff, academic faculty, and general staff experienced in online instruction. Colleges must also assess their training methods and analyze what is required to provide a smooth academic experience for students adjusting to the learning curve associated with transitioning to the digital world.

Online Program Managers (OPMs) are particularly important actors in academic delivery because they provide services such as student recruitment and enrollment, student and graduate retention, market research, course design, and technology platforms (Hodge, 2020). Hodge (2020) further notes that 86\% of 
institutions ranked system integration as the most important factor for online academic delivery, and 77\% reported that they expect OPMs to use data analytics to inform their strategy. An investment in advanced technology that allows various systems to communicate with one another strengthens the outlook of colleges and universities. Data integration is vital during the pandemic as it is difficult to predict how long higher education will remain online.

Unfortunately, higher education trails behind other industries when it comes to digitally-driven, outcome-focused business models as education remains one of the least digitized sectors in the US economy. There is an opportunity for technology to be a leading force in the world of higher education. With remote learning and distance education becoming increasingly common, more platforms and technologies, such as Coursera and EdX Leverage Data, have emerged. Technologically driven institutions like the University of Illinois are affecting the graduate degree market by using technology that reduces faculty labor and scaling programs to thousands of students at a discounted cost, thus retiring traditional residential programs (Gallagher \& Palmer, 2020). Other universities are using machine learning and artificial intelligence (AI) to offer blended learning experiences through AI-based chatbots that assist students with questions and offer support. Evidently, the shift to digitalization in higher education institutions has presented universities with various ways of adjusting academic delivery to fit the changing educational landscape in response to the COVID-19 pandemic.

\section{Effects of the COVID-19 Pandemic on College Major Choices}

The pandemic brought a lot of technological changes to universities. Technology departments are expected to facilitate everyday activities including, but not limited to, setting up student software accounts, video calls, phone calls, and emails for the new virtual environment. This increase in information technology jobs at universities is also seen in other industries as employees around the world work remotely due to the pandemic. IT degree holders are earning more, with an average salary of $\$ 61,000$ per year for an individual with a Bachelor of Science in Information Technology (Payscale, 2020). There is increased demand for IT workers, and universities and other education programs are working hard to supply the industry with the needed talent. Fortune Magazine reported that initiatives such as the RECONNECT program, which allows Tennessee residents to attend Tennessee community college for free, encourage technology-based education programs and ease access to education programs for IT and computer science (Beacon Hill Marketing, 2015). The program helps students get a foundation in technology-oriented programs and enables Tennessee to move toward a more computer-friendly environment, which is a requirement for surviving the COVID-19 pandemic.

\section{Effects of the COVID-19 Pandemic on the College Experience}

College students' expectations for their university experience vary, but they typically include greater wealth, more knowledge, and better career opportunities (Green \& Hill, 2003). A survey of 351 first-year university students revealed that student expectations and experiences influence students' university attendance, reporting a positive relation between students' expectations and their experiences (Nadelson, et al., 2013). First-year students have expectations that faculty members will be readily accessible and give them quick feedback on their work (Brinkworth, et al., 2009). However, students' expectations and experience may be misaligned when students have unrealistic expectations and misunderstand the expectations that institutions have of them (Crisp, et al., 2009). Unfortunately, the sudden and unpredictable nature of the COVID-19 pandemic has destabilized expectations. For example, the COVID-19 pandemic has changed the way incoming freshmen select their higher education institutions. With colleges and universities closed, students do not have the opportunity to take on-campus tours or attend overnight events to get the full college experience. Students can only learn from the internet and their high school counselors. To mitigate this problem, the director of admission at Williams College stated that in addition to admissions counselors continuing to answer students' questions via phone, their website now includes diverse profiles and email addresses of current students with whom prospective students can communicate (Shulman, 2020). Colleges and universities are making good use of social platforms to reach their prospective students and 
respond to questions, comments, or concerns. These are just some examples of how schools adjusted to preserve the college experience and accommodate student expectations.

With the shift away from college campuses to online learning, students fear that they will not experience the social aspects of attending a college or university, including joining clubs and various student organizations, interacting with new friends from different backgrounds and cultures, and learning who they are themselves. These social considerations figure in a larger list of student motivations to go to college, which include gaining knowledge and intellectual interest, having more flexible views, becoming more future oriented and efficient in saving money, and making better investments (Schultz \& Higbee, 2007). To address student motivations in the wake of COVID-19, colleges and universities are now forced to examine their online learning experience. For example, the creation of online learning experiences in lieu of oncampus experiences can free-up resources for colleges to design social networks, field-based projects, and global learning experiences, which also present a collective cost reduction for both university and students. Similarly, institutions can use technology to provide content to large general education classes at low costs without worrying about face-to-face interactions since these basic classes typically require less social exchange anyways. (Govindarajan \& Srivastava, 2020).

\section{RESTRUCTURING OF UNIVERSITY RESOURCES DUE TO THE PANDEMIC}

\section{Effects of the COVID-19 Pandemic on University Policies and Human Relations}

Although, in the age of COVID-19, interaction between students, faculty, and staff occurs mostly through technology, it is crucial that higher education institutions perform COVID tests on individuals physically visiting the university. A study of large- and medium-sized colleges (more than 5,000 undergraduates) holding in-person classes showed that only $25 \%$ conduct mass-screening or random-testing of students and only $6 \%$ routinely test all students (Nadworny \& McMinn, 2020). Testing and pandemic control is quite difficult at universities, partly due to a lack of funding for tests and supplies. Universities are already facing an increase in spending on IT costs due to increased video classes, so adding routine COVID testing may put a strain on their budgets. The selection of cheap vs. expensive coronavirus testing kits can drastically impact how many students are tested and how often as COVID-19 test kits range from 10 to 100 dollars. Testing students can be a complex task, especially when testing on a voluntary basis. For instance, during the 2020-2021 academic year, when the University of Mississippi invited its 18,000 students for a voluntary COVID-19 test, only 394 students participated (Nadworny \& McMinn, 2020). In addition to not volunteering for tests, college students are likely to partake in risky behavior. College campus security personnel have broken up parties and other campus gatherings to help decrease the spread of the virus, yet not much seems to work to deter these students.

\section{Effects of the COVID-19 Pandemic on University Finances}

Aligning university services and programs with first-year student expectations requires that university administrators understand first-year student influences and accurately predict enrollment and adjustment capacities (Jackson, et al., 2000). Colleges and universities have reacted differently to the effect of the pandemic on their finances. Some colleges are adjusting their selectivity, rounding-out their freshman classes to ensure they have funding. The decrease in selectivity for top tier institutions, such as Brown, Columbia, Dartmouth, Harvard, MIT, Penn, and Yale, is a result of having received fewer applications for class of 2024 than for class of 2023 (Termont, 2020). In response to the low number of applicants, colleges are admitting a greater proportion of students than they previously had or drawing from their waitlist. For instance, in 2020, Stanford's admission rate increased from 4.34\% to 5.19\%, the first increase since 2004 (Ehsan, 2020). Regardless of admission rules, university funding is further affected as students re-evaluate their decisions and sometimes opt for deferment. That is why, as reported by Sedmak (2020), the overall undergraduate enrollment nationwide for the 2020-2021 academic year is $4 \%$ below the previous year. As students change their plans due to the pandemic, ripple effects appear across the university system.

A decrease in enrollments greatly affected and created budgetary problems for higher education institutions. Due to the pandemic, institutions could not measure the number of prospective students through 
paid deposits, deadlines were pushed from May to June. Even after paying their deposits, $12 \%$ of students no longer planned to attend a 4-year college full time, thus forfeiting the deposit as a reliable gauge of students' commitment (Art \& Science Group LLC., 2020). As presented in FIGURE 3, in the 2017-2018 academic year, tuition and fees made up about $20 \%$ of public universities' revenues, $31 \%$ of private nonprofit universities' revenues, and 94\% of private for-profit universities' revenues (National Center for Education Statistics, 2020). Moreover, about 30\% of public or private universities were operating on deficits (Quintana, 2020), and more than $86 \%$ of college presidents placed fall or summer enrollment numbers as a priority, because 4-year universities were predicted to lose between $\$ 7$ billion and $\$ 19$ billion due to low enrollment in 2020 (Kim, et al., 2020).

In addition to lower enrollment, universities' budgets were impacted by unexpected expenses related to COVID-19, such as extra dorm cleanings and pro-rated room \& board refunds (Smalley, 2020). Those financial constraints combined with lower traffic on campus facilities create uncertainty about faculty and staff jobs and benefits, including health care coverage. Most higher education institutions are going through a period of financial difficulty which has resulted in hiring freezes and furloughs (Kelly \& Columbus, 2020). For instance, in October 2020, the University of Memphis announced plans to cut jobs in areas including, but not limited to, facilities management and support services, housing, parking and transportation services, mail services, and dining services (Connolly, 2020).

FIGURE 3

\section{PERCENTAGE OF REVENUES FROM TUITION \& FEES AT UNIVERSITIES}



National Center for Education Statistics, 2020

\section{CONCLUSION}

The COVID-19 pandemic has greatly affected higher education. The overall undergraduate enrollment has dropped $4 \%$ in the 2020-2021 academic year. However, community colleges, private for-profit online universities, and public universities, while non-profit private universities experienced sharp decreases. Students who decide to defer, attend community colleges, or not attend school in 2020 may not ever go back to their original plans, resulting in a potential for lost earnings had they attended a four-year institution. In addition, the effect on students is unevenly distributed by race and by international versus domestic students (Sedmak, 2020).

Universities also face challenges. Due to decreased enrollment, some universities were forced to be less selective to round out their freshman class. Others were not able to reach their target number of students which lowered the revenue from student tuition. Universities that have reopened faced increased spending in their medical and health departments to keep the student body safe. They also increased spending in IT departments to ensure that academic instruction continued smoothly. Because of the benefits that IT can 
offer to students, some universities and states are encouraging students to pursue IT-related majors to ensure a highly effective workforce in a post-COVID world. Universities are also rethinking the experiences they offer, as they are not able to provide the traditional experience where students can socialize and network. Instead, colleges are focusing on the online experience and are turning to online program management tools to better deliver online content, collect data, and monitor student engagement. Universities are learning to pivot by freeing up resources that would otherwise have been allocated to developing on-campus experiences, shifting these resources to tech platforms that contribute to online experiences, and taking advantage of the benefits of online learning to scale up the volume and reach of their programs. Evidently, the COVID-19 pandemic triggered many changes in decision-making that have altered the landscape of higher education, and the long-term impact of these decisions remains to be seen.

\section{REFERENCES}

Acton, R. (2020). Community college program choices in the wake of local job losses. Brookings: Future of the Middle-Class Initiative. Retrieved from https:/www.brookings.edu/research/communitycollege-program-choices-in-the-wake-of-local-job-losses/

Art \& Science Group LLC. (2020, April 1). Looking ahead to Fall 2020: How Covid-19 continues to influence the choice of college-going students. Retrieved from https://www.artsci.com/studentpoll-covid-19-edition-2

Art \& Science Group LLC. (2020, July 22). A conversation with College Board. Retrieved from https://www.artsci.com/insights

Beacon Hill Marketing. (2015, November 18). Tennessee volunteering resources to kickstart tech education, employment. Retrieved from https://beaconhillstaffing.com/BH-Specialties/BHTechnologies/Insights/Article-Archive/Article-Detail-Archive/xmlid/2074

Beckstein, A. (2020, July 24). How are international students coping with the Covid-19 pandemic? Times Higher Education. Retrieved from https://www.timeshighereducation.com/student/blogs/howare-international-students-coping-covid-19-pandemic

Brinkworth, R., McCann, B., Matthews, C., \& Nordström, K. (2009). First year expectations and experiences: Student and teacher perspectives. Higher Education, 58(2), 157-173.

Connolly, D. (2020, October 13). As U of M plans job cuts, United Campus Workers union seeks community support. Commercial Appeal. Retrieved from

https://www.commercialappeal.com/story/news/2020/10/13/university-memphis-layoffs-job-cutsand-united-campus-workers/5968785002//

Crisp, G., Palmer, E., Turnbull, D., Nettelbeck, T., Ward, L., LeCouteur, A., \& Schneider, L. (2009). First-year student expectations: Results from a university-wide student survey. Journal of University Teaching and Learning Practice, 6(1), 11-26.

Davis, C. (2020, October 10). Small private college enrollment soars during COVID-19. News Channel 5. Retrieved from https://www.newschannel5.com/news/small-private-college-enrollment-soarsduring-covid-19

DeVaney, J., Shimshon, G., Rascoff, M., \& Maggioncalda, J. (2020, May 5). Higher ed needs a long-term plan for virtual learning. Harvard Business Review. Retrieved from https://hbr.org/2020/05/higher-ed-needs-a-long-term-plan-for-virtual-learning

Ehsan, C. (2020, October 31). Stanford admit rate rises to 5.19\%, 378 students defer enrollment. The Stanford Daily. Retrieved from https:/www.stanforddaily.com/2020/10/31/stanford-admit-raterises-to-5-19-378-students-defer-enrollment/

Gallagher, S., \& Palmer, J. (2020, September 29). The pandemic pushed universities online. The change was long overdue. Harvard Business Review. Retrieved from https://hbr.org/2020/09/thepandemic-pushed-universities-online-the-change-was-long-overdue

Govindarajan, V., \& Srivastava, A. (2020, March 31). What the shift to virtual learning could mean for the future of higher ed. Harvard Business Review. Retrieved from https://hbr.org/2020/03/whatthe-shift-to-virtual-learning-could-mean-for-the-future-of-higher-ed 
Green, R.J., \& Hill, J.H. (2003). Sex and higher education: Do men and women attend college for different reasons? College Student Journal, 37(4), 557-563.

Hershbein, B., \& Kearney, M.S. (2014, September 14). Major decisions: What graduates earn over their lifetimes. The Hamilton Project. Retrieved from

https://www.hamiltonproject.org/papers/major_decisions_what_graduates_earn_over_their_lifeti mes

Hodge, E. (2020, October 19). How do OPMs work? Online program management explained. Retrieved from Keystone Academic Solutions: https://www.keystoneacademic.it/news/online-programmanagement-explained

Israel, E., \& Batalova, J. (2021, January 14). International students in the United States. Migration Policy Institute. Retrieved from https://www.migrationpolicy.org/article/international-students-unitedstates-2020

Jackson, L.M., Pancer, S.M., Pratt, M.W., \& Hunsberger, B.E. (2000). Great expectations: The relation between expectancies and adjustment during the transition to university. Journal of Applied Social Psychology, 30(10), 2100-2125.

Kelly, A., \& Columbus, R. (2020). College in the time of coronavirus: Challenges facing American higher education. American Enterprise Institute. Retrieved from https://www.aei.org/wpcontent/uploads/2020/07/College-in-the-Time-of-Coronavirus.pdf

Kim, H., Krishnan, C., Law, J., \& Rounsaville, T. (2020, May 21). COVID-19 and US higher education enrollment: Preparing leaders for fall. McKinsey \& Company. Retrieved from $\mathrm{https} / / / \mathrm{www} . \mathrm{mckinsey} \cdot \mathrm{com} /$ industries/public-and-social-sector/our-insights/covid-19-and-ushigher-education-enrollment-preparing-leaders-for-fall

Kim, J. (2020, April 1). Teaching and learning after COVID-19. Inside Higher Ed. Retrieved from https://www.insidehighered.com/digital-learning/blogs/learning-innovation/teaching-andlearning-after-covid-19

Korn, M. (2020, September 17). Choosing a college during coronavirus: How four students decided. Wall Street Journal. Retrieved from https://www.wsj.com/articles/choosing-a-college-duringcoronavirus-how-four-students-decided-11600315318

Krantz, L., \& Fernandes, D. (2020, August 6). At Harvard, other elite colleges, more students deferring their first year. Boston Globe. Retrieved from https://www.bostonglobe.com/2020/08/06/metro/harvard-other-elite-colleges-more-studentsdeferring-their-first-year/

Marcus, J. (2020, May 29). While focus is on fall, students' choices about college will have a far longer impact. The Washington Post. Retrieved from

https://www.washingtonpost.com/education/2020/05/29/while-focus-is-fall-students-choicesabout-college-will-have-far-longer-impact/

Nadelson, L.S., Semmelroth, C., Martinez, G., Featherstone, M., Fuhriman, C.A., \& Sell, A. (2013). Why did they come here? The influences and expectations of first-year students' college experience. Higher Education Studies, 3(1), 50-62.

Nadworny, E., \& McMinn, S. (2020, October 6). Even in COVID-19 hot spots, many colleges aren't aggressively testing students. National Public Radio. Retrieved from https:/www.npr.org/2020/10/06/919159473/even-in-covid-hot-spots-many-colleges-arentaggressively-testing-students

National Center for Education Statistics. (2020, May). Postsecondary institution revenues. Retrieved from https://nces.ed.gov/programs/coe/indicator_cud.asp

OIR UTK. (2020). 20-year trend of total headcount enrollment by gender and racelethnicity. Knoxville: Office of Institutional Research. Retrieved from https://oira.utk.edu/wpcontent/uploads/sites/66/2020/10/2020-21_Ten-Year-Trend-of-First-Time-Freshman-AppliedAdmitted-and-Enrolled.pdf

Oreopoulos, P., \& Salvanes, K. (2011). Priceless: The nonpecuniary benefits of schooling. Journal of Economic Perspectives, 25(1), 159-184. 
Payscale. (2020, August 29). Bachelor's degree, information technology (IT) degree. Payscale. Retrieved from https://www.payscale.com/research/US/Degree=Bachelor\%27s_Degree\%2C_Information Technology_(IT)/Salary

Quintana, C. (2020, March 20). USA Today. US colleges scrambled to react to the coronavirus pandemic. Now their very existence is in jeopardy. Retrieved from https://www.usatoday.com/story/news/education/2020/03/20/coronavirus-college-studentsonline-class-graduation-commencement-refund/2876589001/

Schultz, J.L., \& Higbee, J.L. (2007). Reasons for attending college: The student point of view. Research \& Teaching in Developmental Education, 23(2), 69-76.

Sedmak, T. (2020, October 15). Fall 2020 undergraduate enrollment down 4\% compared to same time last year. National Student Clearinghouse. Retrieved from https://www.studentclearinghouse.org/ blog/fall-2020-undergraduate-enrollment-down-4-compared-to-same-time-last-year/

Shenoy, R. (2020, March 20). International students displaced by COVID-19 also face headaches with online classes. The World. Retrieved from https://www.pri.org/stories/2020-03-20/internationalstudents-displaced-covid-19-also-face-headaches-online-classes

Shulman, J.M. (2020, March 15). How to make college decisions when campuses are closed. The New York Times. Retrieved from https://www.nytimes.com/2020/03/15/well/family/coronaviruscollege-visits-high-school-students.html

Simpson Scarborough. (2020, August 1). The Impact of COVID-19 on Higher Education. Retrieved from https://impact.simpsonscarborough.com/covid/

Singh, P. (2020, May 11). While colleges struggle to fill Class of 2024, Penn has not yet increased waitlist admissions. The Daily Pennsylvanian. Retrieved from https://www.thedp.com/article/2020/05/penn-waitlist-admissions-coronavirus2

Smalley, A. (2020, July 27). Higher education responses to coronavirus (COVID-19). National Conference of State Legislatures. Retrieved from https://www.ncsl.org/research/education/highereducation-responses-to-coronavirus-covid-19.aspx

Termont, C. (2020). Admission statistics for the class of 2024. Top Tier Admissions. Retrieved from https://www.toptieradmissions.com/counseling/college/2024-ivy-league-admissions-statistics/

Williamson, B. (2020, May 6). Datafication and Automation in Higher Education During and After the COVID-19 Crisis. Code Acts in Education. Retrieved from https://codeactsineducation.word press.com/2020/05/06/datafication-automation-he-covid19-crisis/ 